\title{
Principles on Forests
}

on-legally binding authoritatipe statement of principles for a global consensus on the management, conservation and sustainable development of all types of forests.

\section{Preamble}

(a) The subject of forests is related to the entirc range of environmental and development issues and opportunitics, including the right to socio-economic devclopment on a sustainable basis.

(b) The guiding objective of these principles is to contribute to the management, conservation and sustainable development of forests and to provide for their multiple and complementary functions and uses.

(c) Forestry issues and opportunities should be cxamined in a holistic and balanced manner within the overall context of environment and development, taking into consideration the multiple functions and uscs of forests, including traditional uses, and the likely economic and social stress when these uses are constrained or restricted, as wcll as the potential for development that sustainablc forest management can offer.

(d) These principles reflect a first global consensus on forests. In committing themselves to the prompt implementation of these principles, countries also decide to kecp them under assessment for their adequacy with regard to further international cooperation on forest issucs.

(e) These principles should apply to all types of forcsts, both natural and planted, in all geographic regions and climatic zones, including austral, borcal, subtemperate, temperate, subtropical and tropical.

(f) All types of forests embody complex and unique ccological processes which are the basis for their present and potential capacity to provide resources to satisfy human necds as well as environmental values, and as such their sound management and conservation is of concern to the Governments of the 
countries to which they belong and are of value to local communities and to the environment as a wholc.

(g) Forests are essential to economic development and the maintenance of all forms of life.

(h) Recognizing that the responsibility for forest management, conservation and sustainable development is in many States allocated amon federal/national, statc/provincial and local levels of government, each State, in accordance with its constitution and/or national legislation, should pursue these principles at the appropriate level of government.

\section{Principles/Elements}

1 (a) "States have, in accordance with the Charter of the Unitcd Nations and the principles of international law, the sovereign right to exploit their own resources pursuant to their own environmental policies and have the responsibility to cnsure that activities within their jurisdiction or control do not cause damage to the environment of other States or of arcas beyond the limits of national jurisdiction".

(b) The agreed full incremental cost of achicving benefits associated with forest conservation and sustainable development requires increased international cooperation and should be equitably shared by the international community.

2 (a) States have the sovereign and inalienable right to utilize, manage and develop their forests in accordance with thcir development needs and level of socio-economic development and on the basis of national policics consistent with sustainable development and legislation, including the conversion of such areas for other uses within the overall socio-economic development plan and based on rational land-use policies.

(b) Forest resources and forest lands should be sustainably managed to meet the social, economic, ecological, cultural and spiritual human needs of present and future generations. These needs are for forest products and services, such as wood and wood products, water, food, fodder, medicine, fuel, shelter, employment, recreation, habitats for wildlife, landscape diversity, carbon sinks and reservoirs, and for other forest products. Appropriate measures should be taken to 
protect forests against harmful effects of pollution, including air-borne pollution, fires, pests and diseases in order to maintain their full multiple value.

(c) The provision of timely, reliable and accurate information on forests and forest ecosystems is essential for public understanding and informed decision-making and should be ensured.

(d) Governments should promote and provide opportunities for the participation of interested parties, including local communities and indigenous people, industries, labour, non-governmental organizations and individuals, forest dwellers and women, in the development, implementation and planning of national forest policies.

3 (a) National policies and stratcgies should provide a framework for increased efforts, including the development and strengthening of institutions and programmes for the management, conservation and sustainable development of forests and forest lands.

(b) International institutional arrangements, building on those organizations and mechanisms already in existence, as appropriate, should facilitate international cooperation in the field of forests.

(c) All aspects of environmental protection and social and economic development as they relate to forests and forest lands should be integrated and comprehensive.

4 The vital role of all types of forests in maintaining the ccological processes and balance at the local, national, regional and global levels through, inter alia, their role in protecting fragile ecosystems, watersheds and freshwater resources and as rich storehouses of biodiversity and biological resources and sources of genetic material for biotechnology products, as well as photosynthesis, should be recognized.

5 (a) National forest policies should recognize and duly support the identity, culture and the rights of indigenous people, their communities and other communities and forest dwellers. Appropriate conditions should be promoted for these groups to enable them to have an economic stake in forest use, perform economic activities, and achieve and maintain cultural identity and social organization, as well as adcquate 
levels of livelihood and well-being, through, inter alia, those land tenure arrangements which serve as incentives for the sustainable management of forests.

(b) The full participation of women in all aspects of the management, conservation and sustainable development of forests should be actively promoted.

6 (a) All types of forests play an important role in meeting encrgy requirements through the provision of a renewable source of bio-energy, particularly in developing countrics, and the demands for fuelwood for household and industrial needs should be met through sustainable forest management, afforestation and reforestation. To this cnd, the potential contribution of plantations of both indigenous and introduced species for the provision of both fuel and industrial wood should be recognized.

(b) National policies and programmes should take into account the relationship, where it exists, between the conservation, management and sustainable development of forests and all aspects related to the production, consumption, recycling and/or final disposal of forest products.

(c) Decisions taken on the management, conservation and sustainable development of forest resources should benefit, to the extent practicable, from a comprehensive assessment of economic and non-economic values of forest goods and services and of the environmental costs and benefits. The development and improvement of methodologies for such evaluations should be promoted.

(d) The role of planted forests and permanent agricultural crops as sustainable and environmentally sound sources of renewable energy and industrial raw matcrial should be recognized, enhanced and promoted. Their contribution to the maintenance of ecological processes, to offsetting pressurc on primary/old-growth forest and to providing regional employment and development with the adequate involvement of local inhabitants should be recognized and enhanced.

(e) Natural forests also constitute a source of goods and services, and their conservation, sustainable management and use should be promoted. 
7 (a) Efforts should be made to promote a supportive international economic climate conducive to sustained and environmentally sound development of forests in all countrics, which include, inter alia, the promotion of sustainable patterns of production and consumption, the eradication of poverty and the promotion of food security.

(b) Specific financial resources should be provided to developing countries with significant forest arcas which establish programmes for the conservation of forests including protected natural forest arcas. These resources should be directed notably to economic sectors which would stimulate economic and social substitution activities.

8 (a) Efforts should be undertaken towards the grecning of the world. All countries, notably developed countries, should take positive and transparent action towards rcforcstation, afforestation and forest conservation, as appropriatc.

(b) Efforts to maintain and increase forest cover and forest productivity should be undertaken in ccologically, economically and socially sound ways through the rehabilitation, reforestation and re-establishment of trces and forests on unproductive, degraded and deforested lands, as well as through the management of existing forest resources.

(c) The implementation of national policics and programmes aimed at forest management, conscrvation and sustainable development, particularly in developing countrics, should be supported by international financial and technical cooperation, including through the private sector, where appropriate.

(d) Sustainable forest management and use should be carricd out in accordance with national devclopment policics and priorities and on the basis of environmentally sound national guidelines. In the formulation of such guidelines, account should be taken, as appropriate and if applicable, of relevant internationally agreed methodologies and criteria.

(e) Forest management should be integrated with management of adjacent areas so as to maintain ecological balance and sustainable productivity.

(f) National policies and/or legislation aimed at management, conservation and sustainable development of forcsts should 
include the protection of ecologically viable representative or unique examples of forests, including primary/old-growth forests, cultural, spiritual, historical, religious and other unique and valued forests of national importance.

(g) Access to biological resources, including genctic material, shall be with due regard to the sovereign rights of the countries where the forests are located and to the sharing on mutually agreed terms of technology and profits from biotechnology products that are derived from these resources.

(h) National policies should ensure that environmental impact assessments should be carried out wherc actions are likcly to have significant adverse impacts on important forest resources, and where such actions are subject to a decision of a competent national authority.

(a) The efforts of developing countries to strengthen the management, conservation and sustainable development of their forest resources should be supported by the international community, taking into account the importance of redressing external indebtedness, particularly where aggravated by the net transfer of resources to developed countries, as well as the problem of achieving at least the replacement value of forests through improved market access for forest products, especially processed products. In this respect, special attention should also be given to the countries undergoing the process of transition to market economies.

(b) The problems that hinder efforts to attain the conservation and sustainable use of forest resources and that stem from the lack of alternative options available to local communitics, in particular the urban poor and poor rural populations who are economically and socially dependent on forests and forest resources, should be addressed by Governments and the international community.

(c) National policy formulation with respect to all types of forests should take account of the pressures and demands imposed on forest ecosystems and resources from influencing factors outside the forest sector, and intersectoral means of dealing with these pressures and demands should be sought.

10 New and additional financial resources should be provided to developing countries to enable them to sustainably manage, 
conserve and develop their forest resources, including through afforestation, reforestation and combating deforestation and forcst and land degradation.

11 In order to enable, in particular, developing countrics to enhance their endogenous capacity and to better manage, conserve and develop their forest resources, the access to and transfer of environmentally sound technologies and corresponding know-how on favourable terms, including on concessional and preferential terms, as mutually agreed, in accordance with the relevant provisions of Agenda 21, should be promoted, facilitated and financed, as appropriate.

12 (a) Scientific research, forest inventories and assessments carricd out by national institutions which take into account, where relevant, biological, physical, social and cconomic variables, as well as technological devclopment and its application in the field of sustainable forest management, conservation and development, should be strengthened through effective modalities, including international cooperation. In this context, attention should also be given to research and development of sustainably harvested non-wood products.

(b) National and, where appropriate, regional and international institutional capabilities in education, training, science, technology, economics, anthropology and social aspects of forests and forest management are essential to the conservation and sustainable development of forests and should be strengthened.

(c) International exchange of information on the results of forest and forest management research and development should be enhanced and broadened, as appropriate, making full use of education and training institutions, including those in the private sector.

(d) Appropriate indigenous capacity and local knowledge regarding the conservation and sustainable development of forests should, through institutional and financial support, and in collaboration with the people in local communities concerned, be recognized, respected, recorded, developed and, as appropriate, introduced in the implementation of programmes. Benefits arising from the utilization of indigenous knowledge should therefore be equitably shared with such people. 
13 (a) Trade in forest products should be based on non-discriminatory and multilaterally agreed rulcs and procedures consistent with international trade law and practices. In this context, open and frec international trade in forest products should be facilitated.

(b) Reduction or removal of tariff barriers and impediments to the provision of better market access and better prices for higher value-added forest products and their local processing should be encouraged to enable producer countries to better conserve and manage their renewable forest resources.

(c) Incorporation of environmental costs and bencfits into market forces and mechanisms, in order to achieve forest conscrvation and sustainable development, should be encouraged both domestically and internationally.

(d) Forest conservation and sustainable development policies should be integrated with economic, trade and other relevant policies.

(e) Fiscal, trade, industrial, transportation and other policics and practices that may lead to forest degradation should be avoided. Adequate policies, aimed at management, conservation and sustainable devclopment of forests, including where appropriate, incentives, should be encouraged.

14 Unilateral measures, incompatible with international obligations or agreements, to restrict and/or ban international trade in timber or other forest products should be removed or avoided, in order to attain long-term sustainable forest management.

15 Pollutants, particularly air-borne pollutants, including those responsible for acidic deposition, that are harmful to the health of forest ecosystems at the local, national, regional and global levels should be controlled. 